\title{
СТАНОВЛЕННЯ ЕКОЛОГІЧНОЇ ОСВІТИ У КРИВОРІЗЬКОМУ ДЕРЖКАВНОМУ ПЕДАГОГІЧНОМУ УНІВЕРСИТЕТІ
}

\author{
Н. В. Гнілуша* \\ Криворізъкий державний педагогічний університет, \\ м. Кривий Ріг, Украӥна
}

\begin{abstract}
Анотація. Політичні та соціально-економічні перетворювання в сучасному суспільстві актуалізують нові запити системі освіти та основні напрямки iї реформування. Створена на основі демократичних і еколого-гуманістичних орієнтирів система загальної та вищої освіти покликана забезпечити підготовку творчо активної особистості, здатної будувати свою країну як суспільство, що розвивається на принципах соціоприродної гармонії. Метою роботи було теоретичне обгрунтування актуалізації формування екологічної культури освітянської молоді та узагальнення досвіду кафедри ботаніки та екології щодо організації екологічної діяльності. Дослідження проводилося на основі наукових публікацій, що стосуються екологічної освіти та її розвитку на кафедрі ботаніки та екології Криворізького державного педагогічного університету.
\end{abstract}

Зазначається, що новому періоду розвитку людства має відповідати нова філософія освіти, нові освітні системи, нові моделі навчання. При цьому, одним із найважливіших напрямків модернізації освіти виступає екологічна освіта, котра спрямована на розвиток здібностей та обдарувань вихованців, задоволення їх інтересів та потреб у професійному визначенні.

Розвиток екологічної освіти на кафедрі ботаніки та екології Криворізького державного університету мав три етапи: 1) зародження екологічної освіти (1930-1941 рр.); 2) становлення екологічної совіти (1944-1986 pр.); 3) імплементація екологічної освіти (1986 р. до нашого часу). Найбільш важливими досягненнями екологічної освіти були: створення та активна діяльність наукового та науково-методичного екологічного центру, ліцензування у 2003-2004 н. р. спеціальність «Екологія та охорона навколишнього середовища» освітньо-кваліфікаційного рівня бакалавр, акредитація у 20082009 н. р. цієї спеціальності, проведення у 2002-2009 рр. вісім міжнародних науково-практичних конференції «Проблеми екології та екологічної освіти», видання у 2002-2015 рр. збірника наукових праць «Екологічний вісник» (у 2015 р. відбувся його ребрендинг - нове видання отримало назву Збірник наукових та науково-методичних праць «Екологічний вісник Криворіжжя»), видання низки наукових монографій та статей, підручників, навчальних посібників, методичних рекомендацій екологічної тематики.

У подальшому екологічна освіта на кафедрі ботаніки та екології Криворізького державного педагогічного університету має бути спрямована на: по-перше, підготовку професійних кадрів; по-друге, формування екологічних знань та екологічної культури на неперервній та міждисциплінарній основі.

${ }^{*}$ Corresponding author. E-mail addresses: n.gnilusha@gmail.com 
Ключові слова: екологічна освіта, екологічне виховання, екологічна культура, безперервна екологічна освіта, професійна екологічна освіта, регіональна екологічна освіта.

Bcmyn. Нині у всіх країнах світу йде перетворення освітніх систем. Освіта по своїй сутності вторинна по відношенню до науки, релігії, філософії, які створюють картину Всесвіту. Нова його картина, яка охоплю глобальні проблеми людства, приводить до необхідності нової освіти, яку по праву можна назвати екологічною. Сучасний підхід до екологічної освіти потребує насамперед розвитку екологічної свідомості, виховання нової особистості з екологічним світоглядом. Людина, яка усвідомила себе часткою Всесвіту, яка відчула свій нерозривний зв'язок з природою, психологічно готова до екологічно цілеспрямованої діяльності $[10,11,20]$.

Після конференції в Ріо-де-Жанейро стало ясно, що майбутньому суспільству XXI століття - постіндустріальному, інформаційному повинна відповідати якісно нова екологічно-освітня система, у центрі уваги якої стануть нові природоохоронні цінності $[4,12,20]$.

Викладачі кафедри ботаніки та екології Криворізького державного педагогічного університету завжди сприяли розвитку екологічної освіти та екологічної вихованості у студентів та мешканців нашого регіону.

Mema роботи - теоретичне обірунтування актуалізації формування екологічної культури освітянської молоді та узагальнення досвіду кафедри ботаніки та екології щодо організації екологічної діяльності.

Матеріали та методи досліджсення. Матеріали дослідження: наукові публікації з екологічної освіти та їі розвитку на кафедрі ботаніки та екології Криворізького державного педагогічного університету. Методи дослідження: аналіз і синтез, індукція і дедукція.

Результати та $\ddot{\boldsymbol{x}} \boldsymbol{x}$ обговорення. В історії педагогіки такі вчені як І. Г. Песталоцці, Г. Сковорода, Я. А. Коменський, Ж. Ж. Руссо та ін. приділяли велике значення принципу природовідповідності, де природа виступала провідним фактором виховання та освіти [4].

Дослідження в області екологічної освіти активізуються після прийняття законів щодо охорони природи. У 60-ті роки проблеми охорони природи поступово входять у поле зору педагогічної науки. Ця проблема розглядалась як природничонаукова, що сприяло включенню природоохоронних матеріалів у навчальні програми 3 географії та біології. У 80-ті роки склалась нова область педагогіки: теорія і практика екологічної освіти та виховання, яка мала за мету формування у школярів системи наукових знань, які сприяли би 
сприяючих відповідальному ставленню до природи у всіх видах діяльності [20].

Проблема розвитку екологічної освіти в Україні є важливим завданням, яке потребує нестандартних підходів як з боку освітян, так і з боку державної влади. Велику роботу в розробленні концепції системи змісту екологічної освіти провели українські вчені П. В. Самойленко, Н. А. Пустовіт, А. С. Волкова, М. Ф. Бойко та ін. [10, 12].

У зв'язку із загостренням екологічної ситуації у 80-ті роки та в результаті аналізу досвіду роботи навчальних закладів України, слід відзначити початок інтенсивного вивчення проблеми екологічної освіти та виховання. Дослідження у цьому напрямку галузі були зосереджені на розробці екологічного змісту навчальних курсів, педагогічних умов удосконалення екологічної освіти із врахуванням регіональних особливостей.

$\mathrm{y}$ чинних законодавчих актах [1-3], зокрема, у «Концепції неперервної екологічної освіти та виховання України» [3], наголошується, що у зв'язку із загостренням екологічних проблем перед сучасною педагогічною наукою і практикою постали невідкладні завдання щодо забезпечення підготовки молодого покоління, здатного вивести людство зі стану глибокої екологічної кризи, у якій воно опинилося через незнання або ігнорування законів взаємовідносин людини й природи, споживацьке ставлення до неї.

Настав час виховувати підростаюче покоління не у традиції якомога більше брати від природи, а у притаманному українському народові гармонійному співіснуванні з природою, раціональному використанні та відтворенні їі ресурсів.

У розв'язанні цих питань провідну роль повинна відігравати екологічна освіта. Розвиток вищої екологічної освіти має базуватися на комплексному збалансованому поєднанні природничого, технологічного, економічного, юридичного і соціокультурного підходів.

Аналізуючи наукові праці багатьох науковців, зокрема, М. Дробнохода, В. Крисаченка, Д. Ліхачова, Л. Лук'янової, М. Моісєєва, А. Урсула, Г. Пустовіта, М. Реймерса, Г. Філіпчука та ін., ми підтримуємо думку, що людина у змозі протистояти сучасним глобальним проблемам тільки за умов сформованого екоцентричного типу свідомості, яка можлива лише за умови відповідного рівня освіченості у процесі неперервної екологічної освіти, i, зокрема, під час навчання у вищому навчальному закладі [11].

Роль закладів вищої освіти є провідною у сприйнятті нової освітянської парадигми стійкого розвитку. Освіта для такого сталого 
розвитку спрямована на розвиток можливостей людини до постійного навчання, що сприяє переорієнтації цілей навчання.

Розвиток екологічної освіти на кафедрі ботаніки та екології Криворізького державного університету мав наступні етапи: 1) зародження екологічної освіти (1930-1941рр.); 2) становлення екологічної освіти (1944-1986 рр.); 3) імплементація екологічної освіти (1986 р. до нашого часу).

Зародження екологічної освіти (1930-1941рр.). Викладачі кафедри ботаніки та екології з самого початку своєї діяльності завжди намагалися сформувати у студентів особливе ставлення до рослинного світу та природи рідного краю. Історичні умови того часу мало сприяли екологічній освіті студентів у сучасному розумінні. Проте викладачі і кафедри, і природничого факультету інтуїтивно поширювали ідеї гуманного ставлення до природи. Про це свідчать їх наукові публікації $[9,19]$. Саме в цей період був заснований Ботанічний сад Криворізького державного педагогічного університету [7, 8, 17]. Сам факт його створення, активна участь студентів і викладачів кафедри у збереженні колекції Саду також можна вважати елементами екологічного виховання та екологічної освіти.

Становлення екологічної совіти (1944-1986 рр.). Відразу після відновлення діяльності Криворізького державного педагогічного університету викладачі кафедри ботаніки та екології взяли активну участь у відновлені рідного міста та його благоустрої. При цьому основний вектор діяльності викладачів був спрямований на дослідження існуючих та створення нових зелених насаджень $[5,6,13]$. Більш змістовно про це наведено у публікації «Історія фіторекультиваційних досліджень і проектної діяльності кафедри ботаніки та екології Криворізького державного педагогічного університету» поточного випуску «Екологічний вісник Криворіжжя».

У цей період, незважаючи на діючі природоохоронні законодавчі акти, не можливо було голосно говорити про наявність будь-яких проблем у суспільстві, у тому числі, і екологічних. Тому діяльність викладачів кафедри ботаніки та екології була в основному спрямована на реалізацію конкретних заходів з озеленення Криворіжжя та на накопичення і осмислення певних теоретичних відомостей з актуальних екологічних проблем $[7,8,13,14,18]$. Завдяки цьому і був сформований теоретичний підмурок екологічної освіти та відбулося її становлення.

Імплементачія екологічної освіти (1986 р. до нашого часу). Саме у цей період кафедра ботаніки та екології Криворізького державного 
педагогічного університету, як окрема група Комплексної експедиції Дніпропетровського національного університету, розвиває творчі ідеї О. Л. Бельгарда, А. П. Травлєєва і І. А. Добровольського, та проводить екологічні і природоохоронні дослідження Криворізького регіону, спрямовані на оптимізацію техногенних ландшафтів, теорію та практику зеленого будівництва, рекультиваціїю відвалів та шламосховищ гірничозбагачувальних комбінатів [15-17].

Сформувати на високому рівні екологічну готовність молодих вчителів лише зусиллями спеціальних кафедр факультету природознавства в педагогічному університеті стало неможливо. Особливої гостроти ця проблема набуває на всіх факультетах, за винятком природничого, географічного і факультету початкових класів. У зв'язку з цим виникає потреба у підвищенні ролі всіх кафедр в екологічній підготовці студентів, а також координації їх діяльності.

Реально функцію координуючого центру став виконувати науковий та науково-методичний екологічний центр, створений на базі кафедри ботаніки та екології Криворізького державного педагогічного університету.

Завданнями екологічного центру є:

1. Координація наукових екологічних досліджень та іншої екологічної діяльності вищих і середніх спеціальних закладів.

2. Удосконалення форм і методів взаємодії з органами місцевого самоврядування та громадськими екологічними організаціями.

3. Широке залучення студентів усіх факультетів до участі у роботі екологічного центру.

4. Надання науково-методичної допомоги з організації та здійсненню екологічної, краєзнавчої, природоохоронної роботи в середніх спеціальних і загальноосвітніх навчальних закладах та на факультетах університету.

5. Покращення науково-методичного забезпечення екологічної підготовки студентів усіх факультетів університету.

6. Інформування вчителів загальноосвітніх навчальних закладів про наукові екологічні дослідження, стан довкілля в Кривбасі та Україні.

7. Організація обміну досвідом екологічної та природоохоронної роботи вчителів загальноосвітніх навчальних закладів.

8. Пропаганда екологічних, природоохоронних, краєзнавчих знань i заходів у засобах масової інформації. 


\section{ОСНОВНЕ СПРЯМУВАННЯ РОБОТИ ЕКОЛОГІЧНОГО ЦЕНТРУ:}

науково-методичне та науково-практичне.

Напрямки роботи центру:
1. Організаційний.
2. Науковий.

3. Науково-методичний.

4. Інформаційний.

1. Організаційний - загальне планування та координація роботи, налагодження зв'язків з державними та недержавними установами, середніми загальноосвітніми навчальними закладами, підготовка i проведення заходів.

2. Науковий - керівництво науковою роботою в галузях екології, охорони природи, екологічної освіти.

3. Науково-методичний - розробка проектів і методичних рекомендацій для методичних об'єднань біологів і географів, шкіл, гімназій і ліцеїв міста; здійснення та впровадження проектів і розробок в освітніх закладах різного рівня акредитації, у тому числі і в університеті.

\section{4. Інформаційний-}

4.1. Збір, накопичення, обробка, узагальнення інформації, забезпечення інформацією про стан довкілля, екологічні та природоохоронні дослідження.

4.2. Пропаганда екологічних та природоохоронних знань.

У межах екологічного центру об'єднуються студентські проблемні групи, які досліджують проблеми стану природного середовища i екологічного виховання школярів. Це залучення студентів до підготовки курсових і кваліфікаційних робіт з проблеми; їх участь у конкурсі на кращу наукову роботу.

При цьому, основними проблемами дослідження є:

1. Вивчення стану природного середовища на регіональному рівні.

2. Удосконалення процесу еколого-краєзнавчої освіти студентів.

У 2003-2004 н. р. на базі кафедри ботаніки та екології Криворізького державного педагогічного університету ліцензовано спеціальність «Екологія та охорона навколишнього середовища» освітньокваліфікаційного рівня бакалавр, а в 2008-2009 н. р. успішно проведена іiі акредитація, що дало можливість розвивати професійну екологічну освіту. Поповнення та зміцнення навчально-методичної бази кафедри 
було спрямоване на підготовку студентів за спеціальностями «Екологія та охорона навколишнього середовища», «Біологія і практична психологія».

У 2002-2015 pр. на базі кафедри ботаніки та екології Криворізького державного педагогічного університету видавався збірник наукових праць «Екологічний вісник», де публікувалися результати екологічних досліджень (теоретичних, практичних, методичних), а також статті 3 екологічної освіти та методики викладання природничих дисциплін.

У 2015 р. відбулася зміна назви цього видання. Нове видання збірника наукових та науково-методичних праць отримало назву «Екологічний вісник Криворіжжя». За останні роки вийшли друком чотири випуски збірника наукових та науково-методичних праць «Екологічний вісник Криворіжжя». У 2019 р. це видання успішно пройшло чергову Державну реєстрацію та отримало відповідне свідоцтво (КВ № 24109-13949 ПР від 22.07.2019) як наукове, науковопопулярне та наукове-методичне видання.

У 2002-2009 pр. на базі кафедри ботаніки та екологї Криворізького державного педагогічного університету було проведено вісім Міжнародних науково-практичних конференції «Проблеми екології та екологічної освіти». Тематика цих наукових форумів охоплювала широке коле питань, пов'язаних з фундаментальними та прикладними проблемами сучасної екології, а також екологічної освіти. У різні роки членами редакційної колегії цих Міжнародних науково-практичних конференції були: член кореспондент Національної академії наук України А. П. Травлєєв; професори: Н. М. Цветкова, В. М. Зверковський, Ю. І. Грицан, А. І. Горова, М. Г. Сметана, С. М. Крамарьов, І. П. Мороз, І. С. Паранько, В. І. Шанда; доценти: Н. В. Гнілуша (академік МАБЖ), Л. В. Григоренко, С. В. Рева, В. М. Савосько. За результатами роботи Міжнародних науково-практичних конференцій «Проблеми екології та екологічної освіти» було випущено вісім друкованих видань, де містилися матеріали цих конференцій. Загальний обсяг цих видань становив понад сто умовних друкованих аркушів, загальна кількість публікацій понад - 630 статей та тез.

Висновки. Становлення та розвиток екологічної освіти на кафедрі ботаніки та екології Криворізького державного педагогічного університету $є$ логічним віддзеркалюванням загальнодержавних та загально світових тенденцій. Екологічна освіта на кафедрі має два основних напрямки: виховання у дусі загальних ідей охорони природи і бережливого ставлення до неї та набуття спеціальних 
професійних знань про загальні закономірності існування природних та антропогенних екосистем. Обидва ці напрямки взаємопов'язані, бо в ïx основах лежить пізнання принципів та закономірностей екології.

Розвиток екологічної освіти на кафедрі ботаніки та екології Криворізького державного університету мав три етапи: 1) зародження екологічної освіти (1930-1941рр.); 2) становлення екологічної освіти (1944-1986 рр.); 3) імплементація екологічної освіти (1986 р. до нашого часу). Найбільш важливими досягненнями екологічної освіти були: створення та активна діяльність наукового та науковометодичного екологічного центру, ліцензування у 2003-2004 н.р. спеціальність «Екологія та охорона навколишнього середовища» освітньо-кваліфікаційного рівня бакалавр, акредитація у 2008-2009 н. р. цієі спеціальності, проведення у 2002-2009 рр. вісім Міжнародних науково-практичних конференції «Проблеми екології та екологічної освіти», видання у 2002-2015 pр. збірника наукових праць «Екологічний вісник» (у 2015 р. відбувся його ребрендинг нове видання отримало назву Збірник наукових та науково-методичних праць «Екологічний вісник Криворіжжя»), видання низки наукових монографій та статей, підручників, навчальних посібників, методичних рекомендацій екологічної тематики.

У подальшому екологічна освіта на кафедрі ботаніки та екології Криворізького державного педагогічного університету має бути спрямована на: по-перше, підготовку професійних кадрів, по-друге, формування екологічних знань та екологічної культури на неперервній та міждисциплінарній основі.

\section{Reference}

1. Zakon Ukrainy Pro osvitu [Law of Ukraine On Education]. (2017). Vidomosti Verkhovnoi Rady [Information of the Verkhovna Rada], 3839, 380. Retrieved from https://zakon.rada.gov.ua/laws/show/2145-19

2. Ukaz Prezydenta Ukrainy [Decree of the President of Ukraine] (2013). Pro Natsionalnu stratehiiu rozvytku osvity $v$ Ukraini na period do 2021 roku [About the National Strategy for the Development of Education in Ukraine until 2021]. Retrieved from https://zakon.rada.gov.ua/laws/show/344/2013

3. Kontseptsiia ekolohichnoi osvity $\mathrm{v}$ Ukraini [The concept of environmental education in Ukraine] (2002). Informatsiinyi zbirnyk 
Ministerstva osvity i nauky Ukrainy [Informative collection of Education and Science Ministry of Ukraine], 7, 3-23. (in Ukraine).

4. Boichenko, S. V., \& Naienko, T. V. (2013). Ekolohichna osvita - osnova staloho rozvytku suspilstva [Environmental education is the basis for sustainable development of society]. Ukraine University. (in Ukraine).

5. Dobrovol'sky, I. A. (1957). Zeleni nasadzhennia Kryvorizhzhia [Green plantations of Kryvyi Rih District]. Naukovi zapysky Kryvorizkoho derzhavnoho pedahohichnoho universytetu [Scientific notes of Kryvyi Rih State Pedagogical University], 11, 117-130. (in Ukraine).

6. Dobrovol'sky, I. A. (1960). Derevni nasadzhennia Inhuletskykh lisovykh dach [Tree plantations of Ingulets forest dachs]. In Shchorichnyk Ukrainskoho botanichnoho tovarystva /Yearbook of the Ukrainian Botanical Society] (Vol. 2, pp. 37-38). Publishing House of the Academy of Sciences of the Ukrainian SSR. (in Ukraine).

7. Dobrovol'sky, I. A. (1967). Dendrariy Krivorozhskogo pedagogicheskogo instituta [The Arboretum of the Kryvyi Rih Pedagogical Institute]. Byulleten glavnogo botanicheskogo sada [Bulletin of the main botanical garden], 65, 8-13. (in Russian).

8. Dobrovol'sky, I. A. (1968). Rezultaty introduktsii ta aklimatyzatsii dekoratyvnykh derev ta chaharnykovykh porid u Kryvorizkomu baseini za roky Radianskoi vlady [The introduction and acclimatization results of the Ornamental trees and shrubs at Kryvyi Rih Basin during the years of Soviet rule]. In: Introduktsiya ta aklimatyzatsiya roslyn na Ukraini [Introduction and Acclimatization of Plants in Ukraine] (Vol. 3, pp. 8-27). Naukova Dumka. (in Ukraine).

9. Fasulati, K. K. (1941). Do vivchennya biotsenoziv Prichornomorskogo solonchakovo-solontsevogo kompleksu [To study the biocenoses of the Black Sea saline complex]. Naukovi zapiski Krivorizhskogo derzhavnogo pedagogIchnogo Institutu [Scientific notes of Kryvyi Rih State Pedagogical Institute], 1, 71-108. (in Ukraine).

10. Gnilusha, N.V., \& Shanda, V. I. (2003). Priorytetni napriamky roboty kafedry botaniky ta ekolohii KDPU [Priority directions of the Botany and Ecology Departmen KSPU]. In: Proceedings of the Second International Conference "Problems of Ecology and Environmental Education" (Vol. 2, pp. 4-5). Etude-Service LLC. (in Ukraine).

11. Gnilusha, N.V., \& Kalnina, A.A. (2019). Teoretychni aspekty doslidzhennia likarskykh roslyn [Theoretical aspects of medicinal 
plants'research]. Ekolohichnyi visnyk Kryvorizhzhia [Ecological Bulletin of Kryvyi Rih District], 4, 135-142. https://doi.org/10.31812/ecobulletin-krd.v4i0.2580. (in Ukrainian).

12. Kvitko, M. O., Mogir, S.P., \& Aleksandrova, O. A. (2019). Dosvid rozvytku ekolohichnoho vykhovannia v Kryvorizkii zahalnoosvitnii shkoli I-III stupeniv № 108 [Experience of development of environmental education in Kryvyi Rih general school № 108]. Ekolohichnyi visnyk Kryvorizhzhia [Ecological Bulletin of Kryvyi Rih District], 4, 143-150. https://doi.org/10.31812/eco-bulletin-krd.v4i0.2586 (in Ukrainian).

13. Shanda, V.I. (1986). Khaos: realnist i obiekt teorii roslynnykh uhrupovan [Chaos: the reality and object of the plant communities theory]. Pytannia stepovoho lisoznavstva ta lisovoi rekultyvatsii zemel [Issues of steppe forestry and forest reclamation of soils], 16, 90-96. (in Ukraine).

14. Shanda, V.I. (1990). Obrysy teorii promyslovoi botaniky [Outlines of the industrial botany theory]. Pytannia stepovoho lisoznavstva ta lisovoi rekultyvatsii zemel [Issues of steppe forestry and forest reclamation of soils], 20, 56-61. (in Ukraine).

15. Shanda, V.I. (2013). Teoretychni problemy ekolohii ta biheotsenolohii [Theoretical problems of ecology and biogeocenology]. Publishing house R. A. Kozlov. (in Ukraine).

16. Shanda, V.I., Yevtushenko E. O., Voroshylova N. V., \& Malenko Ya. V. (2016). Ahrofitotsenolohiia: aspekty teorii, metodolohii ta sumizhnykh nauk [Agrophytothenology: aspects of theory, methodology and related sciences]. Publishing house D. O. Chernyavsky. (in Ukraine).

17. Tovstolyk, N. M., \& Tovstolyk N. V. (2012). Profesor I. A. Dobrovolskyi ta yoho pryrodnychi doslidzhennia Prydniprovia [Professor I. A. Dobrovolsky and his natural research of the Dnipro District]. Istoriia $i$ kultura Prydniprovia: Nevidomi ta malovidomi storinky [History and culture of the Dnipro District: Unknown and little-known pages], 9, 89-95. (in Ukraine).

18. Traytak, D. I. (1960). Poshirennya paporotey v okolitsyah m. Krivogo Rogu [Ferns'distribution in the vicinity of Kryvyi Rih City]. Schorichnik Ukrayinskogo botanIchnogo tovaristva (Yearbook of the Ukrainian Botanical Society], 63-64. (in Ukraine).

19. Zadiraka, P. M. (1941). Do vivchennya bioekologichnih osoblivostey krapchastogo hovraha (Citellus suslicus odessanus Nord) [To study 
the bioecological features of the spotted ground squirrel (Citellus suslicus odessanus Nord)]. Naukovi zapiski Krivorizhskogo derzhavnogo pedagogIchnogo Institutu [Scientific notes of Kryvyi Rih State Pedagogical Institute], 1, 109-138. (in Ukraine).

20. Zverev, I. D. (1980). Jekologija v shkol'nom obuchenii: novyj aspekt $v$ obrazovanii [Ecology in schooling: a new aspect in education]. Znanie [Knowledge]. (in Russian).

\title{
ESTABLISHMENT OF ENVIRONMENTAL EDUCATION AT KRYVYI RIH STATE PEDAGOGICAL UNIVERSITY
}

\author{
N. V. Gnilusha
}

Kryvyi Rih State Pedagogical Unsversity, Kryvyi Rih, Ukraine

\begin{abstract}
Political and socio-economic transformations in modern society actualize new demands on the education system and the main directions of its reform. The system of school and higher education, which is created on the basis of democratic and ecological-humanistic guidelines, is designed to provide training for creatively active individuals who are able to build their country. At the same time, the new society must develop on the principles of social and natural harmony. Object of work: actualization of the formation of ecological culture of educational youth and generalization of the experience of the Department of Botany and Ecology on the organization of ecological activity was theoretically substantiated. This study was conducted on the basis of scientific publications related to environmental education and its development at the Department of Botany and Ecology at Kryvyi Rih State Pedagogical University. It is noted that for a new period of human development must meet a new philosophy of education, new educational systems, new models of learning. At the same time, one of the most important areas of modernization of education is environmental education. This education is aimed at developing the abilities and talents of students, meeting their interests and needs in professional determination.

The development of environmental education at the Department of Botany and Ecology of Kryvyi Rih State University had three stages: 1) the emergence of environmental education (1930-1941); 2) the formation of the environmental council (1944-1986); 3) implementation of environmental education (1986 to the present).

The most important achievements of environmental education were: 1) creation and activity of the scientific and scientific-methodical ecological center; 2) licensing in 2003-2004 academic year specialty "Ecology and Environmental Protection" educational qualification level bachelor; 3) accreditation in 2008-2009 academic year this specialty; 4) holding in 2002-2009 eight International scientific-practical conferences "Problems of ecology and ecological education";5) publication in 2002-2015 of the collection of scientific works "Ecological Bulletin" (in 2015 it was rebranded - the new edition was called the Collection of scientific and scientific-methodical works "Ecological Bulletin of Kryvyi Rih District"); 6) publication of a number of scientific monographs and articles, textbooks, manuals, methodological recommendations on environmental issues,
\end{abstract}


In the future, environmental education at the Department of Botany and Ecology of Kryvyi Rih State Pedagogical University should be aimed at: first, training of professional staff; secondly, the formation of environmental knowledge and environmental culture on a continuous and interdisciplinary basis.

Keywords: ecological education, ecological education, ecological culture, continuous ecological education, professional ecological education, regional ecological education.

\section{Citation as:}

Gnilusha, N. V. (2020). Stanovlennia ekolohichnoi osvity u Kryvorizkomu derzhavnomu pedahohichnomu universyteti

APA [Establishment of environmental education at Kryvyi Rih State Pedagogical University]. Ekolohichnyi visnyk Kryvorizhzhia [Ecological Bulletin of Kryvyi Rih District], 5, 31-42. https://doi.org/10.31812/eco-bulletin-krd.v5i0.4352.

Гнілуша Н.В. Становлення екологічної освіти у Криворізькому державному педагогічному університеті. Екологічний Вісник Криворіжсжя. 2020. Вип. 5. С. 31-42. 